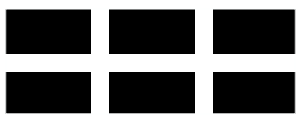

THE WILLIAM DAVIDSON INSTITUTE AT THE UNIVERSITY OF MICHIGAN BUSINESS SCHOOL

\title{
Ecology and Violence: The Environmental Dimensions of War
}

\author{
By: Timothy L. Fort and Cindy A. Schipani
}

William Davidson Institute Working Paper Number 698

May 2004 


\title{
ECOLOGY AND VIOLENCE: THE ENVIRONMENTAL \\ DIMENSIONS OF WAR ${ }^{\dagger}$
}

\author{
by \\ Timothy L. Fort* \\ and \\ Cindy A. Schipani**
}

\begin{abstract}
Research reported by Thomas Homer-Dixon characterizes five social effects that can significantly increase the likelihood of violence in the emerging world, effects that are far deeper than can be controlled by security forces: (1) constrained agricultural production, often in ecologically marginal regions; (2) constrained economic productivity, mainly affecting people who are highly dependent on environmental resources and who are ecologically and economically marginal; (3) migration of these affected people in search of better lives; (4) greater segmentation of society, usually along existing ethnic cleavages; and (5) disruption of institutions, especially the state. ${ }^{1}$ These kinds of social effects create tensions that can erupt in violent expression. It is difficult to envision how additional security forces will solve the embedded social problems that link violence with economic, social, ethnic, and even religious frustrations.

This manuscript seeks to address these concerns. Part I elaborates ways in which these issues of violence manifest themselves in a globalized economy. Part II discusses the business implications of these tensions and suggests a way in which business can be a mediating actor to

${ }^{\dagger}$ Copyright Timothy L. Fort and Cindy A. Schipani (2003). All rights reserved. Forthcoming in the COLUMBIA JOURNAL OF ENVIRONMENTAL LAW.

*Associate Professor, University of Michigan; Co-Area Director for Corporate Governance and Corporate Responsibility, The William Davidson Institute; Co-Director, Center for Corporate Governance and Sustainable Peace, University of Michigan Business School.

** Professor, University of Michigan; Co-Area Director, Corporate Governance and Corporate Responsibility, The William Davidson Institute; Co-Director, Center for Corporate Governance and Sustainable Peace, University of Michigan Business School.

${ }^{1}$ Thomas Homer-Dixon, EnVironment, ScArcity, AND Violence 80 (1999).
\end{abstract}


lessen these tensions. Part III concludes with a suggestion for a recharacterization of the corporation in a way to sensitize it to the ecological-mindedness necessary to address the potential issues of violence in societies.

We propose sustainable peace as an aim to which businesses should orient their actions both for reasons of the good of avoiding the activities that contribute to the spilling of blood as well as for the good of sustainable economic enterprises, which are fostered by stable, peaceful relationships. Thus, business must do what it does best and address economic development, even in terms of the extraction of natural resources. But it must also be attentive to the rights of others, to the development of community and meaning, and to stop violence when it is likely. Given the dangers ecological stresses pose for the planet, it is hard to think of a more compelling reason to reorient business behavior.

Keywords: environmental law; peace; social responsibility; corporate governance JEL Classification: K22; K23; M14 
"[E]nvironmental forces transcend borders and oceans to threaten directly the health, prosperity and jobs of American citizens.... [A]ddressing natural resource issues is frequently critical to achieving political and economic stability, and to pursuing our strategic goals around the world," according to then U.S. Secretary of State Warren Christopher, in the spring of $1996 .{ }^{2}$ "The next war in our region will be over the waters of the Nile, not politics," observed Boutros Boutros-Ghali in 1988, then Egypt's minister of state for foreign affairs. "3usiness is business, and capital, money, is a coward. It is drawn to places which have the rule of law, places where there is an accountability of government, educated healthy workforces, secure working conditions. Capital will flee - money will flee from corruption, bad policies. It will flee from conflict. It will flee from sickness," according to U.S. Secretary of State Colin Powell in fall of $2001 .^{4}$

From the pronouncements of these foreign policy leaders, it seems that business people have a profound interest in a stable allocation of natural resources as well as an environment relatively free from violent conflict. ${ }^{5}$ The consequences of war involve the destruction of both human life and natural resources and directly impact business. For instance, in the conflict between East Timor and Indonesia that began in the mid-1970s, the Indonesian Air Force's use of napalm was not only a psychologically effective weapon against guerilla forces, it also destroyed forests, crops, and livestock, poisoned land and water and started forest fires. ${ }^{6}$ In the 1991 Gulf War, smoke and pollution from sabotaged oil wells reduced the life expectancy of at least 50,000 people, and between 1990 and 1992 infant mortality increased by 100\%. ${ }^{7}$ The destruction of water purification and sewage facilities resulted in raw, untreated sewage and chemicals being dumped into rivers and streets. As a result, incidences of hepatitis increased from 1,816 cases in 1989 to 13,776 cases in $1992 .{ }^{8}$ Thirty percent of hospital water was also

\footnotetext{
${ }^{2}$ Quoted in Paul Hawken, Amory Lovins, and L. Hunter Lovins, Natural CaPitalism: Creating the NeXt INDUSTRIAL REVOLUTION 20 (1999).

${ }^{3}$ Quoted in Michael T. Klare, Resource Wars: The New Landscape of Global Conflict 12 (2001).

${ }^{4}$ Quoted in Ted C. Fishman, The Myth of Capital's Good Intentions, HARPER's MAGAZINE, August 2002, at 34 (Fishman rejects Powell's statement, arguing that business makes a great deal of money from war and instability). ${ }^{5}$ Because the term "environment" can also refer to legal, governmental, cultural, and social issues in addition to those relating to ecology, we primarily use the word "ecological" rather than "environmental" to designate the connection of violence, business, and the natural world.

${ }^{6}$ Ian Robinson, The East Timor Conflict, in The True Cost of Conflict: Seven Recent Wars And TheIr EFFECT ON SOCIETY (Michael Cranna, ed. 1994) 10-11.

${ }^{7}$ Gregory Quinn, The Iraq Conflict, in THE TRUE COST OF CONFLICT, supra note 5, at 26.

${ }^{8} I d$. at 29 .
} 
contaminated. ${ }^{9}$ Thus, human and natural resources vital for the operation of business were destroyed.

In Kashmir, extensive deforestation resulted from skirmishes between India and Pakistan and 150,000 Kashmiri Hindus were relegated to refugee camps with limited health care. ${ }^{10}$ The refugee situation was even more pronounced in the conflict in Mozambique from 1980-1992, where over five million people were displaced internally and 1.7 million others fled to other countries. ${ }^{11}$ Deforestation has been a problem here too as has the destabilization of coastal mangroves and coral ecosystems. ${ }^{12}$

Location and disruption of public health infrastructures can have further devastating impacts on the rise of diseases; this may be a central aim of combatants. In the Sudan, for instance, retreating troops intentionally destroyed hospitals and other health facilities. ${ }^{13}$ With depleted medical care, incidents of malaria, typhoid, TB, and meningitis have now become common in southern Sudan. ${ }^{14}$ The destruction of infrastructure generally has left people with no other choice than to turn to wood as a fuel, thus prompting deforestation; this also accelerates desertification of soil, and with fewer windbreaks, more topsoil is blown away by desert winds. ${ }^{15}$

Of course, the results of warfare do not create the kind of conditions in which businesses typically flourish and the loss of economic vitality in each of these areas has been documented. ${ }^{16}$ Yet, the connection between problematic social effects, violence, and economics runs deep because industrialization of the global economy exacerbates social tensions. ${ }^{17}$ Not surprisingly, the fastest growing industry around the world is security and private police protection; this was true even before the terrorist attacks of September $11,2001{ }^{18}$ Security systems may provide a measure of stability and protection from violence, but the dynamics driving tensions around the globe are much deeper than can be controlled by adding additional (private or public) police

\footnotetext{
${ }^{9}$ Id. at 33 .

${ }^{10}$ Nils Bhinda, The Kashmir Conflict, in THE TRUE COST OF CONFLICT, supra note 5, at 64-65.

${ }^{11}$ Shaun Vincent, The Mozambique Conflict, in THE TRUE CosT OF ConfLICT, supra note 5, at 93.

${ }^{12} I d$. at 92 (stating that the area of mangrove forest has declined 70 percent, and coastal erosion threatens the livelihood of 55,000 families dependent on the fishing industry).

${ }^{13}$ Nicholas Shalita, The Sudan Conflict, in THE TRUE COST OF CONFLICT, supra note 5, at 138 (finding that government troops destroyed the equipment and buildings of the only two functioning hospitals in 1992).

${ }^{14} I d$. at 139.

${ }^{15} I d$. at 145 .

${ }^{16}$ See generally, THE TRUE COST OF CONFLICT, supra note 5 (discussing several world conflicts and how they have depressed the economies of countries around the world).

${ }^{17}$ HAWKEN, ET AL, supra note 1, at 8.

${ }^{18} I d$.
} 
officers. At least in liberal societies, which most of the richest countries of the world emulate, ${ }^{19}$ extra security measures are likely to be a necessary but insufficient component of a solution toward the kind of stability needed for business to thrive.

Indeed, research reported by Thomas Homer-Dixon characterizes five social effects that can significantly increase the likelihood of violence in the world, and are more complex than can be controlled by security forces: (1) constrained agricultural production, often in ecologically marginal regions; (2) constrained economic productivity, mainly affecting people who are highly dependent on environmental resources and who are ecologically and economically marginal; (3) migration of these affected people in search of better lives; (4) greater segmentation of society, usually along existing ethnic cleavages; and (5) disruption of institutions, especially the state. ${ }^{20}$ These kinds of social effects create tensions that can erupt in violent expression. It is difficult to envision how additional security forces will solve the embedded social problems that link violence with economic, social, ethnic, and even religious frustrations.

This Article seeks to address these concerns. Section I elaborates ways in which these issues of violence manifest themselves in a globalized economy. Section II discusses the business implications of these tensions and suggests a way in which business can be a mediating actor to lessen these tensions. Section III addresses a related issue concerning war and disease. The Article concludes with a suggestion for a recharacterization of the corporation in a way to sensitize it to the ecological issues necessary to address the potential issues of violence in societies.

\section{The Relationship Between the Physical Environmental and War}

This section describes four ways in which ecological issues connect with warfare and directly impact violence. These involve: (1) resource scarcity resulting in competition for resources; (2) exacerbation of identity-based tensions, resulting from either competition for scarce resources or from ecological degradation; (3) the impact of disease either as a weapon in its own right or as a consequence of the degradation of infrastructure; and (4) broader issues of sustainability in the face of increasing populations and increasing industrialization.

\footnotetext{
${ }^{19}$ See generally AMY CHUA, WORLD On FIRE: How EXPORTING FREE MARKET DEMOCRACY BREEDS ETHNIC HATRED AND GLOBAL INSTABILITY (2003) (arguing that the simultaneous adoption of majority-rule democracies and free markets is a recipe for violent, ethnic clashes in developing countries).

20 ThOMAs HOMER-DiXON, ENVIRONMENT, SCARCITY, AND VIOLENCE 80 (1999).
} 


\section{A. Resource Scarcity and Implications for Business}

Contests among nations and states for valuable resources are nothing new. Much of colonial history resonates with the drive for acquisition of material goods, whether gold, spices, fur, or other items. The days of European conquests of the New World may have abated, but violent contests for natural resources still occur throughout the world. Consider in Africa, ${ }^{21}$ the Democratic Republic of the Congo, where six countries are fighting to control gold, copper, diamonds, and timber. ${ }^{22}$ Although Western interests in Middle Eastern oil tend to be more concerned with protecting access to petroleum rather than controlling it to the exclusion of other countries, it is not inconceivable that disputes for oil could turn into battles over controlling the resource.

The raw contest for control of resources by nation-states who simply need or desire wealth is one example of how the physical environment connects with potential conflict. Michael Klare names three other kinds of conflict, where the control over the natural resource is connected to genuine sovereign claims of nation-states. ${ }^{23}$ The first of these occurs when the supply of a natural resource extends across the boundaries of adjoining sovereign states. This is the case, Klare says, with an underground oil basin or a large river system. ${ }^{24}$ As noted in the opening quotation from Boutros Boutrous-Ghali, Egypt's insistence on controlling the waters of the Nile has historically put it at odds with upstream African nations, such as Ethiopia and the Sudan. ${ }^{25}$ Similarly, the concern that an adjoining country that shares a resource might make excessive use of it was one of Iraq's complaints against Kuwait in $1990 .{ }^{26}$ A second point of contention can arise with respect to an offshore mineral resource where, by exercising sovereign rights of up to two hundred miles under the United Nations Convention on the Law of the Sea, ${ }^{27}$ multiple states may claim ownership of minerals located in relatively small bodies of water, such

\footnotetext{
${ }^{21}$ See, e.g. GEORgE B.N. AyITTEY, AFRICA IN CHAOS 5-6 (1998) (noting the vast material wealth of the African continent and the interest of countries in exploiting that wealth).

${ }^{22}$ Fishman, supra note 3, at 37.

${ }^{23}$ See generally, KLARE, supra note 2.

${ }^{24}$ Id. at 19.

${ }^{25}$ See, Robert O. Collins, The Nile (2002) (for a history of the ecological dimensions of the Nile River, particularly as effected by various hydroelectric projects, the attempts to control the river, and the geopolitical rivalries spawned by issues of such control).

${ }^{26}$ Id. at 22. See also Philip K. Verleger, Understanding the 1990 Oil Crisis, THE ENERGY J., Oct. 1990, at 15 (asserting that preceding Iraq's invasion of Kuwait, Iraqi President Saddam Hussein claimed that Kuwait was stealing oil from the disputed Rumaila field and producing in excess of its OPEC quota).

${ }^{27}$ United Nations Convention on the Law of the Sea, Dec. 10, 1982, 21 I.L.M 1261.
} 
as in the Caspian Sea. ${ }^{28}$ Third, disputes over control of bodies of water, such as the Persian Gulf or the Suez Canal may cause conflict as well. ${ }^{29}$

Disputes over any of these four resource-based issues may well spill over into other contests relating to ethnic tensions, as will be described later, but they are important in their own right. In particular, consider the potential problems with respect to the resources of oil and water.

\section{Mixing Oil and Water: The Economization of Foreign Policy}

Oil and water are critical for industry. ${ }^{30}$ Moreover, oil and water are also finite resources that can foreseeably become exhausted in the twenty-first century. Estimates of global oil supplies suggest that there is enough oil to sustain global requirements into the middle part of the century with potentially significant shortages occurring in the second or third decade of this century. ${ }^{31}$ Similarly, although the earth has vast quantities of water, only three percent is fresh water, including a significant amount of that in polar ice caps and glaciers. ${ }^{32}$ With population growth and higher standards of living, the middle part of the twenty-first century may also see $100 \%$ usage of the available supply of fresh water. ${ }^{33}$

Similarly, petroleum-based fuels currently account for ninety-five percent of the world's consumed transportation energy. ${ }^{34}$ There is every reason to believe that the demand for oil, for both transportation and other energy uses, will increase substantially in the future, particularly in Asia and Latin America. ${ }^{35}$ In China and India alone, countries home to almost half of the world's population, oil consumption is projected to rise 3.8\% annually. ${ }^{36}$ From 1990 to 1996,

\footnotetext{
${ }^{28}$ KLARE, supra note 2, at 22. See also Paul Thomas, Geopolitics Around the Caspian, EnERGy ECONOMIST, Sept. 1993, at 16 (explaining the various regions surrounding the Caspian and Aral Seas and the conflicts and politics therein).

${ }^{29}$ KLARE, supra note 2, at 22.

${ }^{30} I d$. at 19.

${ }^{31}$ Id. See also James J. MacKenzie, Heading Off the Permanent Oil Crisis, Issues IN SCI. AND TeCH., Jun. 1996, at 48 (finding that the rate of production of oil producing countries will decline rapidly in the coming years as crude oil supplies are consumed).

${ }^{32}$ KLARE, supra note 2, at 19. See also Barry James, Less Water and Less to Eat, InT'L HerALD TRIBUNE, Oct. 2002, at 1 (asserting that only one percent of fresh water is available for human use, as the remainder is trapped in the ice caps and glaciers).

${ }^{33}$ KLARE, supra note 2, at 19.

${ }^{34} \mathrm{Id}$. at $36-37$.

${ }^{35} \mathrm{Id}$. at 38 (Asia and Latin America are particularly susceptible to increases in need for fuel due to development and rapid industrialization).

${ }^{36} I d$.
} 
the Chinese economy expanded by $93 \%{ }^{37}$ The Department of Energy expects energy consumption to grow by 3.4\% annually in Brazil, 3.0\% in Mexico, and 3.7\% in India between 1997 and $2020 .^{38}$ It is estimated that by 2020 , these four countries will require 151 quadrillion BTUs of energy, or three times the amount needed in $1990 .{ }^{39}$ With such increasing demands, pressure will likely be applied to the supply of petroleum. Based on studies done by BP Amoco, there are 1,033 billion barrels of oil in existing reservoirs that could be extracted under "existing economic and operating conditions." $" 40$ Others estimate additional "unproven" reserves of 200 to 900 billion barrels. If the unproven reserves are averaged so as to expect a supply of 1,600 billion barrels being consumed as a current rate of 73 million barrels a day (as of 1999), the current supply would only satisfy demand for sixty years. ${ }^{41}$ This estimate itself places exhaustion of oil supplies within the life expectancies of children born at the turn of the millennium, but if the Department of Energy's projection that worldwide oil consumption will rise by 1.9 percent per year between 1998 and 2020 is correct, the resulting consumption of 113 million barrels of oil a day would result in depletion of world oil stocks by 2040 rather than by $2060 .{ }^{42}$

This supply-demand dynamic places the reliance on fuel for industrialization and transportation within sight of exhaustion. ${ }^{43}$ This could mean that countries will develop other sources to fuel economic development. It also could mean that the intensity of competition for oil could increase. Because of this dynamic, it is not surprising that many countries have now announced "the economization of foreign policy." 44

Without undertaking a long historical analysis of the connection between economic gain and foreign policy, three important moments in the last sixty years - 1941, 1973-74, and 1989 demonstrate why countries tend to consider natural resources a cornerstone of their foreign policy. In World War II, for instance, Japan's attempt to gain control over the Dutch East Indies oil producing region triggered the 1941 U.S. oil export embargo on Japan, which in turn led

\footnotetext{
${ }^{37}$ Id. at 16 .

${ }^{38} \mathrm{Id}$. at 17; see also INTERNATIONAL ENERGY OUTLOOK, available at http://www.eia.doe.gov/oiaf/ieo.

${ }^{39}$ KLARE, supra note 2, at 17.

${ }^{40} \mathrm{Id}$. at 41 .

${ }^{41} \mathrm{Id}$. at 42 (noting that this is a conservative estimate that assumes a static rate of global consumption).

${ }^{42} I d$.

${ }^{43}$ Id. at $42-43$.

${ }^{44} \mathrm{Id}$. at 10 (this economization is a result of giving more strategic significance to economic and research concerns, i.e. U.S. protection of critical resources and trade routes).
} 
Japan to conclude that war with the United States was inevitable. ${ }^{45}$ Meanwhile, Germany's need for oil prompted, at least in part, its 1941 invasion of the Soviet Union. ${ }^{46}$ The 1973-74 disruption of oil supplies to the West by oil exporting countries in the Middle East not only prompted the West to look for other oil supplies (such as in the North Sea and Alaska), but also led to pronouncements by Secretary of State Henry Kissinger in 1975 and by President Jimmy Carter in 1980 that the U.S. would go to war to protect Persian Gulf oil supplies. ${ }^{47}$ Since the end of the Cold War in 1989, emerging and post-communist countries have tried to adapt to the free market and, in doing so, faced the issue of the need for resources to support economic development. Thus, Russia's President Putin, in 2000, announced a doctrine in which one of the purposes of the country's military would be the "creation of the conditions for the security of economic activity and protection of the Russian Federation's national interests in the territorial seas, on the continental shelf, and in the exclusive [offshore] economic zone of the Russian Federation and on the high seas." 48 Similarly, China has focused more of its military attention on the South China Sea, with its reserves of petroleum and natural gas, and Japan has adopted a defense program to protect shipping lanes around the country. ${ }^{49}$ In part, these efforts are simply a continuation of any sovereign's attempt to protect resources important to a given political entity, but when economic development becomes central to a country's foreign policy, then protection of resources necessary for that development becomes critical. ${ }^{50}$

This economization of foreign policy has two particularly significant consequences. First, competition is increasingly acute because the supply of oil is concentrated in a few places, a concentration sometimes called the "Strategic Triangle." 51 Second, the competition is not simply among nation-states, but businesses, particularly multinational corporations, are also enmeshed in the competition among countries.

\footnotetext{
${ }^{45}$ Id. at 31. See also Eric Black, Why Did Japan Decide to Attack Pearl Harbor?, STAR TRIB. (MinNEAPOLIS-ST. PAUL), May 25, 2001, at 11A (asserting that Japan had no intention to attack Pearl Harbor until the U.S. embargo drove them to seek out the Dutch East Indies region and to try and stop the U.S. Navy from interfering with the plans).

${ }^{46}$ KLARE, supra note 2, at 31.

${ }^{47} \mathrm{Id}$. at 33 (Kissinger stated to Business Week magazine that the U.S. would be willing to go to war over oil supplies, although he was reluctant to use force, while Carter asserted that the U.S. would use any means necessary to protect its interests in the Gulf, including military force).

${ }^{48}$ Cited in KLARE, supra note 2, at 11.

${ }^{49}$ Id. See also Ben Barber, Beijing Eyes South China Sea With Sub Purchase, Wash. Times, Mar. 7, 1995, at A13 (stating that China intended to buy 22 submarines from Russia in order to pursue its interests in the Sea).

${ }_{50}$ KLARE, supra note 2, at 14.

${ }^{51} I d$. at 49 (the Strategic Triangle is the region stretching from the Persian Gulf in the west, to the Caspian Sea in the north, and to the South China Sea in the east).
} 


\section{Oil Flashpoints: The Strategic Triangle}

The Strategic Triangle refers to a region stretching from the Persian Gulf to the Caspian Sea and then to the South China Sea. ${ }^{52}$ These areas possess huge, significantly undeveloped sources of oil and natural gas as well as numerous, unresolved territorial disputes. ${ }^{53}$

The issues surrounding the Persian Gulf need little elaboration. The region has been the site of two major interventions by the West, led by the United States and Great Britain, in the past twelve years, as well as the feature of disputes between powers in the region including between Iraq and Kuwait (and various other parties in the 1991 Persian Gulf War) ${ }^{54}$ Iraq and Iran, ${ }^{55}$ Turkey and Syria, ${ }^{56}$ and Turkey and Iraq. ${ }^{57}$ In addition, because of the unequal distribution of oil revenues benefiting royal or business elite, there is resentment within Middle Eastern countries, often linked with religious dimensions, even though the governments of such countries have provided relatively generous benefits to the general population in terms of education, health care, food, and housing. ${ }^{58}$ Connected with the interests of Western countries that have intervened in the region, the volatility of the region is well known. Because of the dangers of relying upon oil from the Middle East, the United States and other countries have sought to diversify by shifting their sources to other regions. ${ }^{59}$ As a result, new areas of development, in regions such as Africa, the Caspian, and Latin America, have become more prominent suppliers of U.S. petroleum needs. ${ }^{60}$ Yet, events suggest that these new locales are not panaceas for stable extraction. The Sudan oil industry, for instance, has become a \$1 million per day profit-maker for the Sudanese government, but the profits seem to have sponsored government war-making capability and activity. ${ }^{61}$ Venezuela, South America's major oil

\footnotetext{
${ }^{52} I d$.

${ }^{53} I d$. at 49-50 (the Strategic Triangle accounts for about half of the current world oil production and three quarters of the currently identified reserves).

${ }^{54}$ John Omicinski, U.S. in for the Long Haul With Persian Gulf Mission, The SeAtTLE Times, Oct. 17, 1997, at A2 (stating that in 1990 Saddam Hussein invaded Kuwait and instigated the Persian Gulf War).

${ }^{55}$ Jay Tolson, Iraq: After Sadaam, U.S. NEWS \& WORLD REP., Apr. 28, 2003, at 27 (chronicling the history of Iraq and the 8 year war that began in the 1990s).

${ }^{56}$ Scott MacLeod, Syria: The Peace Conflict, TIME, Oct. 18, 1999, at 56 (stating that Syria has a crucial dispute with Turkey, since Turkey controls Syria's main water source, the Euphrates).

${ }^{57}$ Jeffrey Fleishman, Turkish-Kurdish Rift Muddles War Plans, L.A. TIMES, Feb. 25, 2003, at A10 (outlining the history of the troubled relationship between Iraq and Turkey).

${ }^{58}$ KLARE, supra note 2, at 53.

${ }^{59} I d$. at 46.

${ }^{60} I d$. (quoting the National Security Council as saying Venezuela has become the number one source, and Africa supplies 15 percent, of oil in the U.S.).

${ }^{61}$ Fishman, supra note 3, at 36.
} 
producing nation, has been gripped by social and labor unrest. $^{62}$ Two additional potential sources for oil and natural gas - The Caspian Sea Region and the South China Sea Region merit further exploration.

\section{a. The Caspian Sea Basin}

The Caspian Sea Basin may hold the world's second or third largest reserve of oil along with a significant amount of natural gas. ${ }^{63}$ Projections of its size are ambiguous, but according to some estimates, it holds as much as 270 billion barrels of oil, approximately twenty percent of the world's proven petroleum reserves, an amount second only to the Persian Gulf's 675 billion barrels. $^{64}$ In addition, the region holds 665 trillion cubic feet of natural gas - about $12 \%$ of the world's total reserves. ${ }^{65}$

The region's attractiveness as a supplier of oil as an alternative to the Middle East has garnered the attention of the United States, but American interests are also of concern to Russia, which considers the Caspian region to be part of its traditional sphere of influence. ${ }^{66}$ Beyond the U.S.-Russian contest for influence, there are "contests boundaries and territorial disputes, the prevalence of authoritarian regimes, severe economic disparities, long-standing regional rivalries, and a cauldron of ethnic and religious strife." ${ }^{, 67}$ These animosities have produced fighting in Uzbekistan, Kyrgyzstan, and Dagestan as well as conflicts between Russia and Chechnya. $^{68}$

Interestingly, however, competition for influence in the Caspian region does not so much involve jockeying among the United States, Russia, local governments, Turkey and Iran, ${ }^{69}$ but among the companies that will do the actual work of drilling, refining, and selling the oil. After all, although governments gain influence and revenues, whether through taxes and fees or, more sinisterly, via bribery and kickbacks, precious few governments actually engage in the oil business. In the Caspian region, the companies seeking to negotiate contracts include BPAmoco, Chevron, Exxon-Mobil, Royal Dutch/Shell, Elf Aquitaine of France, Agip of Italy, Stat-

\footnotetext{
${ }^{62}$ Scott Wilson, Political Deadlock Bolsters Chavez; Venezuelan Leader Exploits General Strike to Remake Institutions, Opponents Say, WASH. Post, Jan. 20, 2003, at A15.

${ }^{63}$ KLARE, supra note 2, at 81.

${ }^{64} I d$. at 2 (citing U.S. Department of Energy figures).

${ }^{65} \mathrm{Id}$.

${ }^{66} \mathrm{Id}$. at 83 .

${ }^{67} \mathrm{Id}$. at 81 .

${ }^{68}$ Id. at 82. See also Chaos in the Caucasus, The ECONOMIST, Oct. 9, 1999, at 23 (quoting newspaper columnists in Moscow as describing the fight between Russia and Chechnya as a war between "civilization and barbarism").

${ }^{69}$ KLARE, supra note 2, at 84 .
} 
oil of Norway, Lukoil of Russia, and the China National Petroleum Corporation, and most attempt to partner with state-owned local concerns. ${ }^{70}$ To succeed, however, the companies and the governments must be able to work without an established framework for determining who has rights to offshore drilling in the Caspian Sea. ${ }^{71}$ Perhaps more significantly, there are also issues concerning how to transport the oil and natural gas to port because the Caspian Sea is landlocked. ${ }^{72}$ As a result, the oil and natural gas will need to pass through pipelines. ${ }^{73}$

Passing oil through pipelines is not a benign decision. Indeed, in Afghanistan, the decisions made to determine where Russian oil should pass had dark consequences. After the Soviet Union withdrew from Afghanistan, the country fell into chaotic struggles for control, with no clear authority in the country. ${ }^{74}$ In 1994, some ex-mujahideen fighters allied with Mullah Mohammed Omar challenged the stronger warlords. In the meantime, several oil companies wished to build a pipeline across Afghanistan to carry oil to Pakistan, seeing the potential for revenue from shipping and transportation if the oil were transferred from Pakistani ports to tankers headed to oil dependent countries. All the while the success of Mullah Omar did not go unnoticed. $^{75}$ Impressed by Omar's success, the Pakistani government provided aid for Omar's group, which the Pakistanis named "the Taliban," to expand its control from Kabul and Kandahar to the rest of the country to secure the corridor necessary for the pipeline. ${ }^{76}$ The subsequent history of the Taliban is now, unfortunately, well known after its support of Osama bin Laden and his Al Qaeda terrorist organization was unearthed. ${ }^{77}$ The interesting feature, however, is that in business's desperate, and to use Secretary of State's Colin Powell's term, cowardly, ${ }^{78}$ need for stability it may seek governmental assistance from sovereigns uninterested in providing justice. In other words, the choices corporations make in maximizing their profitability, particularly in areas of the world where there are major risks of violence, are not benign. The choices to be made by both governments and businesses, in building pipelines, for example, have proven to have significant negative spillover effects.

\footnotetext{
${ }^{70}$ Id. at $86-87$.

${ }^{71}$ Supra notes 65 to 67 and accompanying text.

${ }^{72}$ KLARE, supra note 2, at 88.

${ }^{73} \mathrm{Id}$.

${ }^{74}$ Nazif M. Shahrani, War, Factionalism, and the State in Afghanistan, 104 AM. ANTHROPOLOGIST 715, 720, (2002).

${ }^{75} \mathrm{Id}$.

${ }^{76} I d$.

${ }^{77}$ Michael Elliot, Special Report: The Secret History, TiME, Aug. 12, 2002, at 28 (explaining the history of the disputes for control of Afghanistan and the history of Al Qaeda).

${ }^{78}$ Fishman, supra note 3, at 34.
} 


\section{b. The South China Sea}

As noted above it is anticipated that Asia's economic development will spur additional demand for energy. ${ }^{79}$ China's energy needs are expected to double between the years 2000 and 2020 and Japan's needs are expected to increase by twenty-five percent within the same time period. ${ }^{80}$ Together, this would result in these two countries consuming twenty percent of world energy by 2020 - an amount that is equivalent to the consumption of all of Western Europe and Latin America combined. ${ }^{81}$ China can turn to coal, which it possesses in abundance, but burning coal results in significant air pollution as well as major contributions to greenhouse gases. ${ }^{82}$ Given China's desire to be the dominant Asian power, as well as its desire to not become dependent on foreign sources of energy, one would expect it to turn its attention to the South China Sea, which it has. ${ }^{83}$ In 1992, China formally claimed two islands - the Spratley (a collection of a few hundred rocks, reefs, and inlets covering over eighty thousand square miles, scattered throughout the Sea, and claimed by five other nations) ${ }^{84}$ and the Paracel Islands demonstrating de facto authority over the South China Sea. ${ }^{85}$ In turn, China then provided drilling contracts to several western companies off of the coast of Vietnam and expanded its military force in the region. ${ }^{86}$ That region, bordered on the North by Taiwan and China, on the West by Vietnam, on the South by Indonesia and Malaysia, and on the East by the Philippines, is a vibrant region of burgeoning economic development, as is nearby oil-dependent Japan and South Korea, with their own thirst for crude oil and gas. ${ }^{87}$ In addition, shipping from other areas, such as the Persian Gulf and the Caspian Sea, generally cuts directly across the South China Sea so that control of the Sea implies not only extractive, but also transport sovereignty ${ }^{88}$ It may well be that countries such as Japan, South Korea, and Taiwan wish to benefit from the extraction of oil from the South China Sea, but regardless, control of the Sea creates potential difficulties for

\footnotetext{
${ }^{79}$ Supra notes 35 to 36 and accompanying text.

${ }^{80}$ KLARE, supra note 2, at 113.

${ }^{81} \mathrm{Id}$.

${ }^{82} I d$. at 114 (there are already dangerous levels of air pollution throughout the country, and China's percentage of world carbon emissions is expected to rise from 13 to 21 percent over the next 20 years).

${ }^{83} \mathrm{Id}$. at 117. See also Stephen B. Young, China Holds the Indochina Key, FAR EASTERN ECONOMIC ReVIEW, Jun. 6, 2002, at 24 (describing the takeover of the islands from Vietnam).

${ }^{84}$ KLARE, supra note 2, at 120. See also Young, supra note 82, at 24.

${ }^{85}$ See KLARE, supra note 2, at 116.

${ }^{86} \mathrm{Id}$.

${ }^{87} \mathrm{Id}$ at 117.

${ }^{88}$ See id. at 111-112 (since countries such as Japan and South Korea are dependent, they need to seek to prevent the continued flow of resources through the sea, and whichever country controls the flow has transport sovereignty).
} 
each of these countries. ${ }^{89}$ The explosive part of this scenario involves the overlapping claims for economic development rights in this region and the military means to enforce those claims. ${ }^{90} \mathrm{~A}$ clash already occurred in 1995 between China and the Philippines over a small islet called Mischief Reef. ${ }^{91}$

One question for South China Sea development involves the potential willingness of various countries to go to war for the zones they claim. Although with respect to all oil development involving unsettled claims of sovereign control, whether in Africa, the Caspian Sea, the Middle East, or the South China Sea, the actions taken by corporations to contract with various governments affects geopolitical resolutions of power and influence. Oil, in short, is not simply about governmental decisions, but also about competition among oil companies.

\section{Competition for Water}

Related to the issues presented by competition for oil are the similar and perhaps more volatile issues surrounding competition for water. With almost three hundred river basins crossing national boundaries ${ }^{92}$ and a six-fold increase in worldwide water use between 1900 and $1995,{ }^{93}$ it is not surprising that many commentators predict that contests for water will be a source of violent conflict in the twenty-first century. ${ }^{94}$ Like oil, water crosses boundaries, giving rise to potential disputes over its use. ${ }^{95}$ Additionally, water supply is finite and once readily known supplies are depleted, it is very costly to obtain additional amounts. ${ }^{96}$ And with the use of water so dramatically increasing, flashpoints are bound to occur. An additional unknown factor is the potential impact that may result from changes in the global climate. ${ }^{97}$

More specifically, flashpoints revolve around increasing needs for water as a result of increasing populations. These include both needs for drinking water and water for industrial and

\footnotetext{
${ }^{89} \mathrm{Id}$. at 119-120 (the coastal irregularities and the numerous islands make determining boundaries in the South China Sea extremely difficult).

${ }^{90} I d$. at 118 .

${ }^{91}$ Id. at 125. See also China and the Philippines: Reef Stricken, THE ECONOMIST, May 29, 1999, at 36.

${ }^{92}$ Hussein A. Amery \& Aaron T. Wolf, Water in the Middle East: A Geography of Peace 64 (2000).

${ }^{93} I d$. at 2 (citing 1997 report from the Commission on Sustainable Development).

${ }^{94} \mathrm{Id}$. at 64.

${ }^{95}$ KLARE, supra note 2, at 142.

${ }^{96} \mathrm{Id}$.

${ }^{97} I d$. at 140 (noting that the greenhouse effect will cause temperatures to rise and rainfall patterns to change in different areas of the country - the impact is as of yet unknown).
} 
agricultural use. ${ }^{98}$ The World Bank estimates that each person requires 36 to 72 cubic meters of water annually to survive. ${ }^{99}$ This number does not include agricultural, industrial, and energyrelated production; together, these additional uses dramatically raise each person's yearly needs to approximately 1,000 cubic meters per year, or as much as seventy percent of the world's freshwater supply with the largest use being for agriculture. ${ }^{100}$

The combination of increasing population and inaccessibility of much of the fresh water supply complicates its efficient distribution. Increasing populations mean that more people need water to drink, and more land devoted to agriculture. Yet, most of the world's arable land is already under cultivation, so that to make additional land productive, irrigation will be required. Irrigation is dependent on accessing remote water supplies. ${ }^{101}$ To make matters worse, human beings are able to access less than one percent of the world's fresh water supply because most of the earth's water is trapped in the polar regions and glaciers. ${ }^{102}$ After precipitation, evaporation and transpiration, the balance of the annual replenishment of the earth's water supply amounts to forty thousand cubic kilometers. ${ }^{103}$ Half of this is currently lost through flooding and another twenty-percent is carried off into inaccessible locations, such as Siberia. ${ }^{104}$ This leaves only 12,500 cubic kilometers of water annually renewable for various human uses, an amount that is probably double existing population needs. ${ }^{105}$ Yet, affluence tends to increase water use; for instance, the world's population doubled between 1950 and 1990, but water use (resulting from indoor plumbing, appliances, and the consumption of meat) increased by three hundred percent. ${ }^{106}$ It is foreseeable that, with increased population and increased affluence, human beings could fairly quickly reach all of the renewable freshwater and, although underground aquifers are available, once they are used, they - like oil reserves - cannot be replenished. ${ }^{107}$ Desalinization is a possibility but is currently very costly. An additional perhaps more significant difficulty is that water availability is not evenly dispersed, but is instead concentrated

\footnotetext{
${ }^{98} I d$. at $142-143$.

${ }^{99} \mathrm{Id}$.

${ }^{100} I d$. (citing World Bank statistics).

${ }^{101} I d$. at $143-44$.

${ }^{102} I d$. at 143 .

${ }^{103}$ Id. See also Sandra Postel, Dividing the Waters, TeChNOLOGy Review, Apr. 1, 1997, at 54.

${ }^{104}$ KLARE, supra note 2, at 143-144.

${ }^{105} \mathrm{Id}$. at 144 .

${ }^{106} I d$.

${ }^{107}$ Id. See also Nicolaas van Rijn, What we Have is All There is, THE TORONTO STAR, Sept. 25, 1999 (comparing an underground aquifer to a bank account that's used for withdrawals and never deposits).
} 
in areas that are either already impoverished or also struggling with potential conflicts regarding oil. ${ }^{108}$ The Middle East, North Africa, and South Asia are particularly prone to water shortages and huge population increases. They are also already the subject of territorial disputes, some connected with petroleum. ${ }^{109}$

With many groundwater resources traversing existing national boundaries and with predictions that by 2025 two-thirds of humanity will suffer from moderate to severe water stress, the opening quotation from Boutros Boutros-Ghali ${ }^{110}$ that future wars will be fought over water may bear some truth. In addition to the Nile, which is shared by several countries, four countries share the Tigris-Euphrates system and the Jordan River is shared by three countries and the Palestinian Authority. ${ }^{111}$

In contrast to Boutros-Ghali's assertion that future wars will not be about politics, but water scarcity, it is important to see that politics is inherently a part of the water conflict. First, water conflict tends to exacerbate ethnic tensions that already exist within a given region or country. ${ }^{12}$ Second, the nature of water flow, particularly with respect to rivers, tends to favor the upstream states that control the flow. ${ }^{113}$ Disputes occur not only among countries, but also within countries such as in India, where farmers in adjoining states have fought over irrigation rights to the Cauvery River and even in the United States, when in the 1920s farmers in eastern California sabotaged the aqueduct system carrying water to Los Angeles. ${ }^{114}$

Launching hostilities over water historically has occurred as a result of concerns over prestige, security, and survival. Certainly, the canals and irrigation systems of Egypt, Mesopotamia, and China contributed heavily to each country's economic development and security, ${ }^{115}$ but spectacular projects - such as the building of the Aswan Dam in Egypt - also enhanced the prestige and power of the rulers. ${ }^{116}$ The need to control water supplies remains crucial to each country's security and survival. Egypt's President Anwar el-Sadat, for instance, threatened to bomb water facilities in Ethiopia, where the main contributor to the Nile, the Blue

\footnotetext{
${ }^{108}$ KLARE, supra note 2, at 144-45.

${ }^{109}$ See id. at 140, 145.

${ }^{110} \mathrm{Id}$. at 12 .

${ }^{111}$ Id. at $145-46$.

${ }^{112}$ Infra notes 118-21 and accompanying text.

113 AMERY \& WOLF, supra note 91, at 6.

${ }^{114}$ KLARE, supra note 2, at 147.

${ }^{115} \mathrm{Id}$. at 141.

${ }^{116}$ Id. See also Robert L. Pollock, Mideast Peace? Let's Start With the Rule of Law, THE WALL STREET JOURNAL, Nov. 27, 2002, at A10 (stating that the dam was Nasser's way to "economic salvation").
} 
Nile, originates, if Ethiopia diverted water for irrigation projects. ${ }^{117}$ Similarly, with Egypt, Sudan, Uganda, and Ethiopia all needing to feed burgeoning populations in an arid region of Africa, the danger of conflict grows significantly. ${ }^{118}$

Tensions also exist in the basins of the Tigris-Euphrates and the Indus rivers. These rivers, which provide the only significant amounts of water for their basins, supported a population of approximately five hundred million people in 1998 with one billion people expected by the middle of the twenty-first century. ${ }^{119}$ The people living in these regions are divided ethnically and religiously and the rivers themselves often have deep symbolic meaning, suggesting that disputes over the rivers are likely to take on additional elements beyond that of the access to the water. ${ }^{120}$ In addition, while the Nile features only one power, Egypt, with significant military might, these other basins feature many nation-states with substantial military capability. ${ }^{121}$ Fortunately, these regions have made efforts to negotiate shared water agreements, but there are major demographic and ethnic pressures that could push disputes over water into explosive problems. ${ }^{122}$

Countries sharing the Tigris-Euphrates River, for instance, are heavily dependent on the river for their freshwater needs, given the common aridity of the region. The rivers are responsible for approximately thirty percent of Turkey's needs, eighty-five percent of Syria's needs, and one hundred percent of Iraq's requirements. ${ }^{123}$ In response to this dependence, several countries have constructed dams in order to control floods, generate power, and irrigate land. $^{124}$ Turkey has built three dams on the Euphrates and has plans for others in the Tigris; Syria has built one dam on the Euphrates with plans for another; and Iraq has built dams on both the Euphrates and the Tigris Rivers. ${ }^{125}$ Constructing these dams creates potential for reduced water flow and subsequent disputes for downriver countries heavily dependent on water from the rivers. A dispute of this kind broke out in 1990 when Turkey essentially cut off the Euphrates

\footnotetext{
${ }^{117}$ KLARE, supra note 2, at 153.

${ }^{118} \mathrm{Id}$. at $156-157$ (this population in total is likely to grow by approximately 300 million in the next 50 years).

${ }^{119} \mathrm{Id}$. at 161.

${ }^{120} \mathrm{Id}$. at 162 .

${ }^{121}$ Id. at 164 (The Jordan River basin includes Israel, Jordan, Syria, and the Palestinian Authority; the TigrisEuphrates includes Iran, Iraq, Syria, Turkey, as well as Kurdish areas; the Indus includes Afghanistan, China, India, Pakistan, and Kashmir).

${ }^{122} I d$. at $162-64$.

${ }^{123} I d$. at 175.

${ }^{124}$ Id. at 176. See also Louis Jacobson, Back to Eden: Restoring the Marshes of Iraq, WASH. POST, Apr. 28, 2003, at A11.

${ }^{125}$ KLARE, supra note 2, at 176.
} 
from Iraq and Syria in order to fill the Ataturk Dam Reservoir. ${ }^{126}$ Because the cutoff was taken in the winter before the growing season, practical impacts were minimized, but the capability to control these waters raised serious concerns in downstream Iraq and Syria. ${ }^{127}$ Linked to demands by Turkey for Syria to exercise greater control over groups troublesome to Turkey, this control has resulted in a general sense of unease and potential conflict. ${ }^{128}$ Moreover, greater needs for water to satisfy growing populations suggests the potential for ongoing conflict over the control of water flow. ${ }^{129}$

The Jordan River basin has seen more than its share of violent conflict over the past fifty years. Water stress is a hovering reality in all of the conflicts between Israel and its Arab neighbors. Steps have been taken to attempt to minimize the water-related aspects of this conflict, although there are open questions regarding whether they have satisfactorily taken place. Like the Nile, Tigris, and Euphrates basins, the Jordan basin has also seen tremendous population growth. Nearly seven times the number of people lived in the Jordan basin in the 1970 s as did in the 1920s with additional significant growth expected. ${ }^{130}$ In the 1970 s, the region as a whole began a period of water deficit, where more use was being made of water than was being replenished annually. ${ }^{131}$ Israel in particular, has adopted a water management plan through the importation, rather than the growing, of food; if ninety-percent of an individual's 1,000 annual cubic meters of water needed ${ }^{132}$ are for cereals, it makes sense to import rather than to grow food. ${ }^{133}$

Yet, flashpoints remain because of the basic problem of a growing population in an arid climate. Moreover, as in other cases, the distribution of water is not even. A central point of contention in the basin is the Israeli strategy of protecting the annual recharge of the Mountain Aquifer in the West Bank, from which Israel obtains some of its water. Israelis require Palestinians to obtain permission to sink wells on the West Bank land - where precipitation runoff flows to the Mountain Aquifer and thereby limits Palestinian use of water. ${ }^{134}$ The result

\footnotetext{
${ }^{126} \mathrm{Id}$. at 177 .

${ }^{127}$ Id. at $177-78$.

${ }^{128} \mathrm{Id}$. at 180.

${ }^{129}$ Supra notes $118-21$ and accompanying text.

${ }^{130}$ AMERY \& WOLF, supra note 92, at 21.

${ }^{131} I d$. at xii.

${ }^{132} \mathrm{Id}$. at xiii.

${ }^{133} I d$. at xii.

${ }^{134}$ Id. at 34 .
} 
of this and other policies is that Palestinians have access to one hundred five million cubic meters of groundwater while Israel makes use of four hundred fifty million cubic meters. ${ }^{135}$ Without making judgments as to the relative merits of various allocations, the perception created by this difference fuels animosity in the basin.

\section{Business Complexities}

In recognizing the collisions between resource availability, population growth, and geopolitical quests for power, it is tempting to simply characterize these as issues of concern among nation-states. Yet, this characterization would be simplistic. It is true, for instance, that the contest for the extraction of oil from the Caspian Sea region pits Russia, the United States, Iran, Turkey, and other nations against one another. ${ }^{136}$ Many disputes in the region center around disputed interpretations of the United Nations Convention on the Law of the Sea (UNCLOS) ${ }^{137}$ For example Russia and Iran claim that the Caspian is a lake for which there are

Soviet-Iranian treaties from the 1940s that control exploitation and distribution of resources. ${ }^{138}$ However, if the Caspian is a sea it is under the jurisdiction of UNCLOS. ${ }^{139}$ But nation-states are not the only parties involved. Russian energy firms such as Lukoil and Gazprom and Western companies such as BP-Amoco, Chevron, Exxon-Mobil, Royal Dutch/Shell, Elf Aquitaine, Agip, Stat-oil, and China National Petroleum are also involved. ${ }^{140}$ Pakistan's support of the Taliban in Afghanistan as a way to secure oil transportation was borne of pressures and opportunities presented by oil companies. ${ }^{141}$ Geopolitical control over natural resources provides security in making oil available to fuel tanks, jeeps, and airplanes. Thus, the contests for control over resources is also very much one among business entities as well as governments.

The situation in Africa provides an example of the complexity of business-andgovernment relationships. Although Africa is rife with innumerable disputes, major energy companies have not been prevented from working with local warlords to obtain agreements to

\footnotetext{
${ }^{135} I d$. at 36.

${ }^{136}$ KLARE, supra note 2, at 90-92.

${ }^{137}$ Id. at 99.

${ }^{138} \mathrm{Id}$.

${ }^{139} \mathrm{Id}$.

${ }^{140} \mathrm{Id}$. at $86-90$.

${ }^{141}$ Id.
} 
extract oil. ${ }^{142}$ In this respect, Colin Powell's claim that business will run away from dangerous situations $^{143}$ may not be as compelling as one might expect. Or, to put it otherwise, businesses value stability, but when faced with an opportunity to secure a valuable resource, businesses, like governments, may resort to the methods necessary to benefit their own interest. If this is true, however, there is reason to hold businesses accountable for their actions that contribute to the likelihood of violence; in short, contests for natural resources are not only governmental responsibilities.

The same may be true with respect to water, such as with attempts to privatize water distribution. In Latin America and the Caribbean, for instance, there have been efforts to turn water services over to private ownership. ${ }^{144}$ These efforts are not always warmly embraced, in part because of the specter of trying to profit from a resource that is essential to human survival. In other words, market-oriented solutions may not be perceived as appropriate for a public good, such as clean water.

Oil and water are obvious resources to examine because of their importance to human survivability and economic development. But other natural resources, such as gold, diamonds, timber, and minerals, are valuable. ${ }^{145}$ From the receipts generated by the sale of diamonds, for instance, the governments of Liberia and Sierra Leone are able to pay wages to young boys to fight in civil wars equipped with inexpensive guns. ${ }^{146}$ This is significant in light of a World Bank study that has found a twenty-fold likelihood of a civil war in countries where the primary export is a single undifferentiated commodity. ${ }^{147}$ In Sierra Leone, up to fifty thousand people have been killed since 1991 with hundreds of thousands becoming refugees. ${ }^{148}$ Multinational corporations are in the midst of this problem because of their desire for the commodity; thus DeBeers has been the target of considerable criticism for allegedly buying "blood diamonds.",149

\footnotetext{
${ }^{142}$ Id. at 14 .

${ }^{143}$ Fishman, supra note 3 , at 34.

${ }^{144}$ See, e.g., Terence R. Lee \& Andre Jouravlev, Private Participation in the Provision of Water Services: Alternative means for private participation of water services, (1997), at http://www.thewaterpage.com/PPP\%20Debate\%20Lee2.pdf

${ }^{145}$ KLARE, supra note 2, at 190.

${ }^{146}$ See Fishman, supra note 3, at 37-38.

${ }^{147}$ Paul Collier, The Market for Civil War, ForeIGN Policy, May 1, 2003, at 38.

${ }^{148}$ KLARE, supra note 2, at 192.

${ }^{149}$ Id. at 191-92. See also Thomas W. Dunfee \& Timothy L. Fort, Corporate Hypergoals, Sustainable Peace, and the Adapted Firm, 36 VAND. J. TRANS. L. 563 (2003) (providing a more in-depth analysis of the bloody diamonds controversy).
} 
Not insignificantly, Liberia exported almost three hundred million dollars worth of diamonds to Belgium in 1998. ${ }^{150}$

Contests for lootable resources often entail significant ecological damage, such as with the case of clear-cutting valuable, old-timber forests. ${ }^{151}$ Seventy-two percent of Liberia's 2000 timber trade was done in conjunction with French and Chinese companies. ${ }^{152}$ This exploitation of natural resources was made possible through the arms trade; although not through the sale of fighter jets, AWACS surveillance systems, or nuclear know-how, but from the trade of 640 million small arms and light weapons. ${ }^{153}$ There is nearly one weapon for every person of Mogadishu's 1.3 million population and an AK-47 in Mogadishu can be purchased for merely two hundred dollars. ${ }^{154}$ In Aceh, Indonesia, an automatic rifle can be bought for the equivalent six U.S. dollars. ${ }^{155}$ With hundreds of millions of dollars being gained by the extraction and export of natural resources, with cheap weapons readily available, with impoverished populations having little alternative means of income, it is unrealistic to lay the issue of war and peace at the feet of only nation-states. Many more actors are involved and the very nature of geopolitical balances of power may be changing in response to the growing influence of multinational corporations. ${ }^{156}$

Thus, contests for natural resources are one example of how violence may erupt. Often, however, it is not simply the possession of resources that gives rise to conflict. As already noted, for instance, river basins that are shared by populations with different ethnic and religious memberships make it possible for contests over natural resources to also have a flavor of identity-based conflict. ${ }^{157}$ The Caspian Sea area has long had deep ethnic divisions; and the arrival of competing oil companies has exacerbated those divisions. ${ }^{158}$ The same is true of contests for lootable resources, such as diamonds and timber; they are embedded within historic antagonisms. ${ }^{159}$ As a result, it is also important to examine how ecological issues can inflame identity-based tensions.

\footnotetext{
${ }^{150}$ Fishman, supra note 3 , at 38.

${ }^{151}$ KLARE, supra note 2, at 193-194.

${ }^{152}$ Fishman, supra note 3 , at 38.

${ }^{153} I d$. at 39.

${ }^{154} \mathrm{Id}$.

${ }^{155} \mathrm{Id}$.

${ }_{157}^{156}$ Se generally, Philip BobBitt, The Shield of AChilles: War, PeACE AND the Course OF History (2002).

${ }^{157} \mathrm{Id}$.

${ }^{158}$ KLARE, supra note 2, at 97.

${ }^{159}$ Id. at 190.
} 


\section{B. Exacerbation of Identity Tensions}

In his research on environmental scarcity and its connection to violence, Thomas HomerDixon concludes that scarcity itself does not cause violent conflict, nor rarely does violence have a single cause. ${ }^{160}$ Yet a great deal of violence, particularly with respect to violence occurring within preexisting borders, is causally related to environmental scarcity. ${ }^{161}$ This includes violence that has occurred in Chiapas, Mexico, South Africa, Pakistan, the Philippines, and Haiti. ${ }^{162}$ Homer-Dixon suggests that scarcities of cropland, freshwater, and forests contribute to violence by generating social stress that fosters "subnational insurgencies, ethnic clashes, and urban unrest" and that developing countries are particularly prone to these disturbances because they are typically dependent on natural resources. ${ }^{163}$ Thus, apart from the specific competition for a particular resource, it is also important to see how competition, or the spillover effects from such contests, can contribute to identity-based tensions that, in turn, can result in violence.

\section{Uneven Distribution of Resources}

Just as energy and water resources provide an initial lens through which to examine competition over natural resources, it is helpful to contextualize the issues that can arise from identity-based conflicts. Homer-Dixon notes that forty percent of the people on the planet use fuel-wood, charcoal, straw, or cow dung as their main source of energy and up to sixty percent rely on these fuels for at least a part of their primary energy needs. ${ }^{164}$ More than 1.2 billion people do not have access to clean drinking water. ${ }^{165}$ The allocation of valuable resources is highly desired and the potentially increased marginalization of those mired in this level of poverty is likely to breed resentment. There are at least two ways in which the distribution of resources can exacerbate simmering identity-based tensions.

The first maldistribution concerns resource capture or structural scarcity. ${ }^{166}$ This occurs when some groups in a given society are able to recognize the value of scarce resources and then act to control large percentages of those resources. ${ }^{167}$ Frequently, these powerful groups also

\footnotetext{
${ }^{160}$ HOMER-DiXON, supra note 19 , at 7.

${ }^{161} I d$. at 7.

${ }^{162} I d$.

${ }^{163} \mathrm{Id}$. at 12 .

${ }^{164} I d$. at 13.

${ }^{165} \mathrm{Id}$.

${ }^{166} I d$. at 15.

${ }^{167} I d$.
} 
manipulate the power structure of society to access further resources. ${ }^{168}$ Recently, two authors have provided perspectives on this issue.

Raimo Vayrynen focuses on rent-seeking activities. ${ }^{169}$ Vayrynen describes the use of non-violent rivalries in the creation of "institutional structures and rules that benefit disproportionately some actors and marginalize others." ${ }^{170}$ These structures, Vayrynen argues, are typically applied theoretically to explain domestic inequalities, but they can just as effectively be applied internationally to explain how wealth can be allocated to favored groups through international institutions. ${ }^{171}$ In return for these rents, benefited groups return political services; often resulting in corruption. ${ }^{172}$ Free markets and democratic institutions threaten rentseeking activities because competition is enhanced, the relative power of the state decreases, and the relative power of and opportunities for bribery is decreased. ${ }^{173}$ Generally speaking, Varyrnen argues rent-seeking and corruption foster violence by undermining the social fabric, ${ }^{174}$ however, Varyrnen recognizes the possibility that rent-seeking might not foster violence when there is a perceived level of fairness of the redistribution policies of the state and, in some instances, when a patron-client kind of hierarchy has cultural validity in its own right. Varyrnen concludes that the connection between rent-seeking and corruption and violence and stability is not conclusive; stability is most at risk when the rent-seeking is monopolistic, pervasive, reckless, and centralized. ${ }^{175}$ If the state has lost its power, through for instance, open markets, then it may be unable to keep order. ${ }^{176}$ Consistent with Homer-Dixon's insight, Varyrnen's work maintains that governments are frequently structured to favor certain groups at the expense of others.

Amy Chua provides a similar argument and connects it specifically to ethnic violence. ${ }^{177}$ Chua's argument is that the opportunities presented by free markets have been seized upon by minorities in many countries to significantly enrich themselves, but that majorities in those

\footnotetext{
${ }^{168} \mathrm{Id}$.

${ }^{169}$ RAIMO VAYRYNEN, GLOBALIZATION AND LOCAL VIOLENCE: A THEORY AND EMPIRICAL INQUIRIES Chapter I at 26 (forthcoming) (manuscript on file with authors).

${ }^{170}$ Id. at 26.

${ }^{171}$ Id. at 27.

${ }^{172}$ Id. at 29.

${ }^{173} \mathrm{Id}$. at 30.

${ }^{174} \mathrm{Id}$. at 31-32.

${ }^{175} \mathrm{Id}$. at 33.

${ }^{176} \mathrm{Id}$.

${ }^{177}$ CHUA, supra note 18.
} 
countries remain impoverished. ${ }^{178}$ Market-dominant minorities may be able to establish and to maintain power in a country ${ }^{179}$ - apartheid in South Africa would be an extreme example - and they exist, she argues throughout the world. ${ }^{180}$ She cites the role of the Chinese in the Philippines and elsewhere in Southeast Asia. ${ }^{181}$ In Indonesia, for example, Chinese Indonesians comprise only three percent of the population, but control seventy percent of the economy. ${ }^{182}$ Similar situations exist in Brazil, Ecuador, Guatemala, West Africa, Nigeria, the former Yugoslavia, and Russia. ${ }^{183}$ The concentration of wealth, however, engenders hostility within countries that can be expressed when majority rule democracy comes with it; the majority then has the capability of scapegoating the wealthy minority, almost always with strongly ethnic overtones. ${ }^{184}$ Chua argues further that this dynamic has consistently resulted in actions of mass murder by the minority against the market-dominant majority; Rwanda is another case in point as are actions in Zimbabwe against white farmers and actions against Chinese in Indonesia. ${ }^{185}$ Even more controversially, Chua argues that the same dynamic is at work with respect to Arab resentment of the regionally market-dominant power in the Middle East, Israel, ${ }^{186}$ and against the United States as a globally market-dominant power in the September 11 attacks. ${ }^{187}$ Thus, according to Chua, governments frequently take on the character of a privileged minority group in the position to benefit itself, at least as long as they can effectively control power and make arrangements to minimize opposition.

Environmental scarcity adds to this dynamic. It is one thing to observe that another ethnic group has better cars or homes. It is another if that other group has clean water while one's children suffer from dysentery caused by drinking dirty water. As already demonstrated, this is one of the problematic perceptions articulated in the ongoing disputes between Palestinians and Israelis on the West Bank. ${ }^{188}$ Given the expected population increases in those countries where access to a critical, basic resource such as water is expected to become even

\footnotetext{
${ }^{178} I d$. at 6-7.

${ }^{179} \mathrm{Id}$.

${ }^{180} \mathrm{Id}$.

${ }^{181} \mathrm{Id}$.

${ }^{182} \mathrm{Id}$.

${ }^{183} \mathrm{Id}$.

${ }^{184} \mathrm{Id}$.

${ }^{185} \mathrm{Id}$. at 231.

${ }^{186} \mathrm{Id}$. at 211.

${ }^{187}$ Id. at $230-31$.

${ }^{188}$ Id.
} 
harder to obtain, the prospects that environmental scarcity will provoke increased ethnic hostilities exists. Adding to the potential is the visual connection provided by contemporary telecommunications and the Internet, where impoverished, suffering populations can see the glitter of the West.

A second maldistribution concerns what is done with the leftovers of resource use; that is ecological marginalization. ${ }^{189}$ This scenario occurs when the structural distributions already in place join with population growth so that the poor, again typically from the same impoverished ethnic groups, are forced into ecologically marginal living quarters such as upland hillsides, land subject to desertification, and tropical rain forests. ${ }^{190}$ This psychological resentment is not necessarily different from that of resource distribution generally; but living in a marginalized area contributes to ethnic resentments that can lead to uncontrollable eruptions. As is the case with the location of petroleum and water, these resentments tend to be found in critically important areas of the world. ${ }^{191}$ These places include South Africa, Mexico, Pakistan, India, and China, the latter two countries comprising over forty percent of the world's population. ${ }^{192}$

In both of these cases, the distribution of either benefits in terms of desired resources or costs in terms of living in degrading conditions, does not typically happen across a demographically neutral board. Instead, certain groups tend to be favored while others tend to be disfavored. Environmental scarcity thus sharpens the potential grievances of rivalries that may often already be simmering in a given country.

\section{Struggle to Control Identity}

A related but distinguishable category is the struggle to control identity. The previous discussion concerning the distribution of resources concerned primarily material costs and benefits as well as the social psychological reaction to them, this second category relates to threats to more spiritual identities. These too, can create the conditions for ethnically related violence.

\footnotetext{
${ }^{189}$ HOMER-DiXON, supra note 19 , at 16.

${ }^{190} \mathrm{Id}$.

${ }^{191} \mathrm{Id}$. at $18-19$.

${ }^{192}$ Id.
} 
Rivers often are imbued with spiritual significance. ${ }^{193}$ Whether it be a large river like the Nile, ${ }^{194}$ or the Kunene River separating Angola and Namibia, ${ }^{195}$ bodies of water, like other natural resources often embody a deep manifestation of the identity of people. These identifications are critically important. Thomas Friedman characterizes those things that anchor human beings to a rooted identity as "olive trees" and writes, "[o]live trees are important. They represent everything that roots us, anchors us, identifies us and locates us in this world - whether it be belonging to a family, a community, a tribe, a nation, a religion or, most of all, a place called home." 196

Although globalization allows for greater interaction among people to cooperate on a range of things that bordered-up societies previously could not have allowed, it also means that within countries, there remains the tug of the olive tree. ${ }^{197}$ Re-routing and damming of rivers, clear-cutting forests, and punching holes in the ground can challenge the identities of people for whom these natural things have spiritual significance. Globalization also challenges cultures in that things that were familiar are now gone, replaced by something strange. To the extent this causes consternation in France about the prevalence of Big Macs and Mickey Mouse, this may not be a huge issue. ${ }^{198}$ At the same time, as Friedman argues, when there is a sense that a community has lost control of its economic vitality, as has been the case when financial markets move money in and out of a country virtually overnight, ${ }^{199}$ one is left with the feeling that no one is in charge except for an arbitrary, faceless market. ${ }^{200}$ But, as Israeli political theorist Yaron Ezrahi notes: "The most arbitrary powers in history always hid under the claim of some impersonal logic -God, the laws of nature, the laws of the market - and they always provoked a backlash when morally intolerable discrepancies became glaringly visible. The Enlightenment was really the globalization of science and rationality and the backlash came when every thief, crook, exploiter and fraud claimed that whatever he was doing was necessitated by science and

\footnotetext{
${ }^{193}$ See CoLLINS, supra note 24, (discusses the religious significance of the Nile River to the communities through which the river flows).

${ }^{194}$ See id.

${ }^{195}$ Carol Ezzell, The Himba and the Dam, SCI. AM. (June, 2001) at 81.

196 Thomas L. Friedman, The LeXUS AND the Olive Tree 31 (2000).

${ }^{197} \mathrm{Id}$. at 31 .

${ }^{198}$ Barbara Robinson, Disney Displayed Cultural Ignorance in Planning Paris Park, Las Vegas ReVIEW-Journal, Sept. 3, 1993, at 11B.

${ }^{199}$ Is it at Risk? Globalisation, THE ECONOMIST, Feb. 2, 2002, available at 2002 WL 7245017.

${ }^{200}$ FRIEDMAN, supra note 195, at 191.
} 
logic. The same could happen with globalization." ${ }^{201}$ It is noteworthy that since the end of the Cold War, fewer than ten percent of contemporary wars have begun as interstate conflicts, but issues of religious, ethnic, or national identity have spurred two-thirds of wars. ${ }^{202}$ In the West, where since the Enlightenment, it has been common to hear concerns raised about religious wars, ${ }^{203}$ and statistics that show that over half of the wars had a religious dimension may not be surprising. Yet, it is surprising that religious belief systems, which always venerated peace, are so intimately connected with contemporary conflict.

Scott Appleby, a leading authority on fundamentalist religious groups addresses one aspect of this. Appleby concedes that raising the specter of violence is not normal for most religions, but argues that often the justification for resorting to violence is an argument that the times are not normal. ${ }^{204}$ Indeed, evidence suggests that many times this characterization is made by groups faced with new threats. Appleby argues that religious extremists typically do not mobilize orthodox believers; instead, they concentrate on the young and untutored during a time when outside pressures threaten traditional ways of life. ${ }^{205}$ Thus, by shrinking time and space through communications and transportation technologies, modernity has made it much more likely that Sikhs, Buddhists, Christians, Jews, Hindus, Muslims, and nonbelievers live in close proximity to one another, especially in large urban areas around the world. In this globalized milieu, religious extremism - with the violent intolerance of outsiders - has become the response of choice for a disproportionately influential minority within traditional religious communities that feel threatened by the new pluralism. ${ }^{206}$ If believers, again typically the young and untutored, think they are threatened, then there is an obligation to fight the enemy by any means. ${ }^{207}$ The threat is that orthodoxy has not adequately responded to the secular, pluralistic, materialist, feminist West. ${ }^{208}$ Fundamentalist leaders who are often charismatic mold an attitude of absolute devotion to the will of God, demonizing the infidel, focusing almost exclusively on a very narrow subset of religious doctrine as being the key to religious truth and connecting that

\footnotetext{
${ }^{201}$ Id. at 191.

${ }^{202}$ R. SCOTt Appleby, The Ambivalence of the SACRed: Religion, Violence, and ReCONCiLiation 17 (2000).

${ }^{203}$ See Timothy L. Fort, Religion and Business Ethics: The Lessons from Political Morality, 16 J. Bus. ETHICs 263, 268-69 (1997) (describing the consequentialist concerns of philosophers and legal scholars with respect to the incendiary dimensions of allowing religion to play a part in politics).

${ }^{204}$ APPLEBY, supra note 201, at 88.

${ }^{205} I d$. at 17.

${ }^{206} \mathrm{Id}$. at 58 .

${ }^{207} I d$. at $90-91$.

${ }^{208} I d$.
} 
truth to political goals. ${ }^{209}$ "Thus the religious Zionists of the Ichud Rabbanim and their counterparts in the Gush Emunim emphasize one of the 613 Torah mitzvoth and subordinate the remaining 612 religious duties to its observance - the commandment to settle the land is tantamount to all other commandments." ${ }^{210}$ In short, believers can latch on to a particularly important dimension of religious tradition - in the quoted example, physical real estate - and use adherence to that tradition to express rebellion against a cultural change. Religion can thus be linked to ecological resources and thereby foster additional, militant violence.

Appleby's account is respectful of religion as a whole, noting how religion can also be militantly devoted to peace. ${ }^{211}$ In his account of fundamentalism, extremists distort a religious tradition that might otherwise be a force for nonviolence. A more cynical view of religion, consistent with Varynen's and Chua's analysis of how a minority group can seize control of government and orient policies for personal benefit, is presented by anthropologist Jared Diamond. ${ }^{212}$ Diamond argues that, historically, human beings tended to live in relatively small bands comprised of between five to eighty people, most of them closely related to each other. ${ }^{213}$ Although there were differences among the relative authority of individuals within these groups, a common feature was that the groups were relatively egalitarian. ${ }^{214}$ There were no formal stratification of class hierarchy, no formal legal institutions, such as the police or even codes of law, and no monopolies of information or decision-making. ${ }^{215}$ Yet human beings, beginning in the last few tens of thousands of years, also lived in tribes (usually populated by hundreds of people), clans, and chiefdoms. ${ }^{216}$ Tribes, $^{217}$ like bands, also tended to be relatively egalitarian with little institutional formality. ${ }^{218}$

When chiefdoms arose 7,500 years ago, there was potential for greater conflict because people lived in close proximity with others they did not know. ${ }^{219}$ One solution was for the chief to hold a monopoly on force; ideally, that force would be used for the welfare of all members of

\footnotetext{
${ }^{209} \mathrm{Id}$.

${ }^{210} \mathrm{Id}$.

211 Id. at 7.

${ }^{212}$ Jared Diamond, Guns, Germs, And SteEl, THE FATES OF Human Societies (1999).

${ }^{213}$ Id. at 267.

${ }^{214} \mathrm{Id}$. at 269.

${ }^{215} \mathrm{Id}$.

${ }^{216} \mathrm{Id}$. at 270-71.

${ }^{217}$ Id. at 271.

${ }^{218} \mathrm{Id}$. at 271-73.

${ }^{219} \mathrm{Id}$. at 273.
} 
the chiefdom, but realistically the chief could also be a thief. ${ }^{220}$ A kleptocracy could only flourish if there were reasons for common people to tolerate the transfer of wealth to the elite. ${ }^{221}$ Historically, those reasons were to: (a) disarm the common people and arm the elite; (b) make the common people happy through redistribution of resources; (c) use force to create satisfaction through maintenance of a safe, public order; and (d) create an ideology or religion justifying the theft. ${ }^{222}$ The last solution typically came in the form of a notion of the divine connection of royalty. ${ }^{223}$ Moreover, the state ideology was able to bind non-kin together in conjunction with a common good that would justify even death for the welfare of others. ${ }^{224}$ The idea of dying for the state, however Diamond argues, was unthinkable for bands and tribes. ${ }^{225}$ Patriotism, he argues, was an unknown commodity. ${ }^{226}$ Diamond argues that fanaticism in war was probably unknown until about six thousand years ago, the time when the great world religions emerged. ${ }^{227}$

Regardless of Diamond's conclusions about kleptocracy, the anthropological data concerning bands and tribes on the one hand and chiefdoms (and even larger organizations) on the other suggests potential for violence in a couple of ways. First, within any large religious organization, there may be disaffected members who are reachable by those who articulate the dangers of a materialistic, secular threat. Second, this threat may be articulated in some way by designating an ecological entity as paradigmatic of either that threat or the essential meaning of the religion. This means that natural resources and landmarks which play a prominent role in most religious traditions of any size can be pulled into ecological conflict.

Thus, identity-based conflict can result from ecological issues. This can occur through the sharpening of ethnic grievances resulting from one ethnic group obtaining more of the benefits of natural resources and fewer of the costs of environmental degradation. It can also occur through the symbolic associations that the natural environment may carry, which become important for various reasons to religious believers. Those adherents, whose faith may or may not be associated with a particular organized religion, may have their beliefs molded by attention to a natural, ecological resource.

\footnotetext{
${ }^{220} I d$. at $273-76$.

${ }^{221} \mathrm{Id}$. at 276 .

${ }^{222} \mathrm{Id}$. at 277 .

${ }^{223} I d$. at 277-78 (specifically citing the example of the kings and gods of Hawaii).

${ }^{224} \mathrm{Id}$. at $278,281$.

${ }^{225} \mathrm{Id}$. at 281 .

${ }^{226} \mathrm{Id}$.

${ }^{227}$ Id. at $281-82$.
} 
An overarching issue with respect to sustainability is the extent that a consumptiondriven economy can be supported by the natural environment. Evidence mounts daily that humanity will be confronted this century with major consequences resulting from climate change. $^{228}$ Fossil fuels are thought to be the major cause of the greenhouse gas problem. ${ }^{229}$ A central threat of climate change is a potential partial melting of polar icecaps, which would raise sea levels and cause severe costal flooding. ${ }^{230}$ This connection of fossil fuel and flooding presents an entirely different dimension of the issues of oil and water described above. ${ }^{231}$ Not only may oil and water be depleted, but there are also impacts on cropland scarcity, tropical deforestation, and depleted fish stocks. ${ }^{232}$

The world is faced with a complicated, difficult ecological condition which could provide the breeding ground for many kinds of violence, justified by those who believe that the current system has not treated them fairly. ${ }^{233}$ It may be comforting to believe that these issues are the province of governments. It seems somewhat unrealistic to believe that governments can solve these issues without the engaged thoughtfulness of the business sector.

\section{The Business Implications}

Regardless of whether the evidence is sufficient to insist on the accountability of business to the connection of war and peace, many places around the world are already making the connection. As we have already noted, Shell Oil Co., a company currently recognized for its social responsibility efforts, was once vilified for its alleged complicity in the oppression of the Ogoni people in Nigeria and its alleged involvement in the assassination of rebel leader Ken Saro-Wiwa. ${ }^{234}$ Exxon has faced protests from human rights organizations for not confronting human rights abuses perpetrated by security forces protecting Exxon's pipeline in Indonesia. ${ }^{235}$ Apart from ecological examples, disgruntled consumers attacked McDonald's restaurants by

\footnotetext{
${ }^{228}$ Climate Panel Reaffirms Major Warming Threat, N.Y. TIMES, Jan. 23, 2001, at F8, cited in Donald O. Mayer, Corporate Governance in the Cause of Peace: An Environmental Perspective, 35 VAND. J. TRANS. L. 585, 609 (2002).

229 Id.

${ }^{230}$ Clare Nullis, UN Report Warns of Global Climate Changes, CHI. TRIB., Feb. 20, 2001, at 4.

${ }^{231}$ Mayer, supra note 227, at 617.

${ }^{232}$ HOMER-DiXON, supra note 19 , at 63.

${ }^{233}$ Mayer, supra note 227, at 618.

${ }^{234}$ William E. Newberry \& Thomas N. Gladwin, Shell and Nigerian Oil, in ETHICAL IsSUES IN BusINESS: A PhilosophicAl APPROACH 522 (Thomas Donaldson \& Patricia H. Werhane, eds., $7^{\text {th }}$ ed. 2002).

${ }^{235}$ Jane Perlez, Indonesia's Guerilla War Puts Exxon Under Siege, N.Y. TIMES, July 14, 2002, International Section, at 1 .
} 
breaking windows and smearing the walls with cow dung after it was learned that, contrary to previous announcements, its French fries were cooked in oil containing beef tallow rather than in vegetable oil. $^{236}$ Hindus who had inadvertently violated religious precepts by eating these fries as well as vegetarians were outraged. ${ }^{237}$ In January, 2002, Argentine protestors ransacked a McDonald's restaurant in Buenos Aires ${ }^{238}$ and the McDonald's in Quebec City simply closed and removed all identifying signs in advance of the 2001 Summit of the Americas to avoid attracting the interest of demonstrators. ${ }^{239}$ Protests against banks in Argentina ${ }^{240}$ and Wal-Mart stores in Bonn ${ }^{241}$ are additional examples of how corporations are increasingly targeted as responsible parties for a variety of perceived social injustices.

It may or may not be fair for businesses to be targets for protests and it also may be true that governments are responsible for managing the resulting conflicts. But business is involved in all of these issues. Although it may not be a moral requirement for corporations to take responsibility for the issues connected with violence, it would benefit both business and society if they did. As Thomas Friedman puts it, "Arab nationalism, socialism, fascism or communism while they may have made no economic sense, had a certain inspirational power. But globalization totally lacks this. When you tell a traditional society it has to streamline, downsize and get with the Internet, it is a challenge that is devoid of any redemptive or inspirational force. And that is why, for all of globalization's obvious power to elevate living standards, it is going to be a tough sell to those millions of people who still say a prayer before they ride the elevator." 242

It is plausible that business can do something to contribute to sustainable peace, a peace that endures because it is just. Engaging that connection could well be the free market's way of addressing the social void ${ }^{243}$ that transactional economics cannot. Businesses are engines of economic development that can be beneficial to social harmony. On one hand, through globalization, businesses consistently reach across borders to allow people from far away places

\footnotetext{
${ }^{236}$ Laurie Goodstein, For Hindus and Vegetarians, Surprise at McDonald's Fries, N.Y. TIMES, May 20, 2001, at A1. 
to gain understanding of each other by working together in ways that would otherwise not be possible. Businesses can do this in creating diverse work forces where members of different ethnic groups may work together for a common project - even if that project is simply that of economic profitability - for the first time. Businesses may be able to, on occasion, mediate conflicts between governments. On the other hand, if businesses are viewed as being exploitative, culturally undermining, greedy, or socially insensitive, they can sow the seeds for potential violence.

Thomas Homer-Dixon ${ }^{244}$ argues that protection from the dilemmas concerning environmental scarcity depends on having better governance to protect the environment, human rights, labor standards, and financial transactions despite no global government. ${ }^{245}$ Solving these problems requires, he argues, technical ingenuity. That kind of creativity depends on social ingenuity together with adequate background institutions to support public and semi-public goods such as markets, funding agencies, educational and research institutions, and effective governments. $^{246}$ Other commentators have argued further that the natural world provides business models, such as biological mimicry, that can be source for ecologically sensitive management. ${ }^{247}$ Out of the natural environment, therefore, are models for thinking about how businesses can make significant contributions to sustainable peace.

Regardless of the particular source, approaching issues of ecology and war draw upon the approach we have articulated. That is, preventing war is not about one thing. It is about many things. Business finds itself in the midst of most all of them and, as a result, has some contribution to make to all of them. A balanced approach of economic development, openness to

\footnotetext{
244 See HOMER-DiXON, supra note 19, at 28-31.

${ }^{245} \mathrm{Id}$. at 206-07. Human beings are simply biologically predisposed to work in small groups. Diamond supra note 211. It may be the case that this predisposition has frequent negative consequences, but it is an aspect of human nature that must be acknowledged and, can be utilized for positive outcomes.

${ }^{246}$ Id. at 110 .

${ }^{247}$ HAWKEN, et al., supra note 1, at 15 . As an example of the possibilities of biomimicry: "[b]usiness is switching to imitating biological and ecosystem processes replicating natural methods of production and engineering to manufacture chemicals, materials, and compounds, and soon maybe even microprocessors. Some of the most exciting developments have resulted from emulating nature's life-temperature, low-pressure, solar-powered assembly techniques, whose products rival anything human-made. Science writer Janine Benyus points out that spiders make silk, strong as Kevlar but much tougher, from digested crickets and flies, without needing boiling sulfuric acid and high-temperature extruders. The abalone generates an inner shell twice as tough as our best ceramics, and diatoms make glass, both processes employing seawater with no furnace."
}

HAWKEN, et al., supra note 1 , at 15. 
external evaluation, building community (including ecological citizenry), and track-two diplomacy, can mediate many of the tensions exacerbated by natural resource stresses.

\section{Disease and War}

As products of nature, human beings are also directly affected by ecological and biological elements. Just as human beings need natural resources, particularly water, in order to exist, so also a disruption in biospherical equilibrium can make life impossible. Thus, the issue of disease and war is not neutral when it comes to the lethal nature of disease; war enhances it and sometimes promote it. Nor is business neutral to disease. Outbreaks of disease, such as sudden acute respiratory syndrome, can wreak havoc on economic affairs. So here again, business has an interest in the containment of disease and because war works against that containment, disease can be seen as something of the ultimate ecological challenge to human life - the challenge to our physical bodies.

War can foster deadly diseases as an incidental weapon and by undermining the capability of societies to control their spread. Jared Diamond argues that Europeans were able to have military success and dominance over native populations because Europeans had guns, the nastiest germs, and steel. ${ }^{248}$ In the Spanish conquest of the Incas, Francisco Pizarro's band of 168 soldiers were able to rout an Incan army of eight thousand without any Spanish casualties. ${ }^{249}$ The use of horses, the sharpness of Spanish weapons, and the protective armor provided against Incan clubs turned the Battle of Cajamarca into a spectacle. ${ }^{250}$ Even so, the Spaniards may not have succeeded had not the Incan Empire already been stricken with an epidemic of smallpox for which the Incans had no resistance. ${ }^{251}$ This, according to Diamond, captures one of the essential reason for European imperial success: "diseases transmitted to peoples lacking immunity by invading peoples with considerable immunity." 252 Smallpox was also crucial in South Africa in 1713. ${ }^{253}$ In Hawaii, after being discovered by Captain James Cook in 1778, the native population shrunk from approximately 800,000 to 135,000 in just forty-five years and further shrunk to just under 40,000 by 1896 due to the spread of venereal disease, tuberculosis, measles,

\footnotetext{
${ }^{248}$ Diamond, supra note 211 , at 23.

${ }^{249}$ Id. at 75.

${ }^{250} \mathrm{Id}$. at 76 .

${ }^{251} \mathrm{Id}$. at 77.

${ }^{252} \mathrm{Id}$. at 77 .

${ }^{253}$ Id. at 78 .
} 
mumps, whooping cough, small pox, cholera, leprosy and a disease resembling typhoid fever, all introduced by Westerners. ${ }^{254}$ Between 1520 and 1618, Mexico's population is estimated to have dropped from 20 million to 1.6 million from disease. ${ }^{255}$ For the New World as a whole, the native population is estimated to have been reduced by as much as $95 \%$ within two centuries following Columbus's landing. ${ }^{256}$ More than swords and spears, most of the killings came from smallpox, measles, influenza, typhus, diphtheria, malaria, mumps, pertussis, plague, tuberculosis, and yellow fever. ${ }^{257}$

A possible reason for the lack of immunity of native peoples and the robust immunity of Europeans is the prevalence of domesticated animals. Diamond argues that, with agriculture, a smaller amount of land was able to feed larger groups of people who lived in nomadic huntergatherer bands. ${ }^{258}$ Larger societies possessed their own military advantages over small bands in terms of manpower, but in addition, the domestication of animals led to their trained use. This increased the possibility for specialization once animals were trained and fewer hands were needed to provide food, people could instead make weapons and build buildings and larger governments. ${ }^{259}$ Moreover, because domesticated animals, including household pets such as dogs and cats, carry with them disease, the resulting density of human and animal populations allowed their immune systems to develop, even in the face of highly mutated diseases such as smallpox, measles, and flu. ${ }^{260}$ These mutated diseases may have been frustrated by the immunities of Europeans and their animals, but the diseases faced no resistance from native populations. ${ }^{261}$ Agricultural societies then, with their specialization of labor, their stores of food to feed armies, their ability to support large populations, and their ability to build up resistance to diseases were at a tremendous advantage over populations of native peoples. ${ }^{262}$ As Diamond rather colorfully puts it, a naked farmer has no advantage over a naked hunter-gatherer, but because the farmer breathes out nastier germs (excluding the possibility that he may also have

\footnotetext{
254 Lilikala Kame'eleihiwa, NATIVE LANDS AND Foreign Desires: PeheA La E Pono Ai 141 (1992).

255 Diamond, supra note 211 , at 210.

${ }^{256} \mathrm{Id}$. at 211.

${ }^{257}$ Id. at 211-12.

${ }^{258} \mathrm{Id}$. at 88-90.

${ }^{259} \mathrm{Id}$. at 89-91.

${ }^{260} \mathrm{Id}$. at 92.

${ }^{261} \mathrm{Id}$. at 92.

${ }^{262}$ Id. at 92 .
} 
armor and horse), the farmer is more likely to prevail. ${ }^{263}$ The densities accompanying urban life make the immunity issue even more pronounced. ${ }^{264}$

Globalization and its associated mobility puts people into contact with each other at a rate previously unimagined. ${ }^{265}$ And, not surprisingly, fatal diseases such as AIDS have been linked to infections that seem to have jumped from animals (specifically monkeys in Africa) to human beings and have spread very quickly around the world due to mobility and the lack of immunity to the disease. ${ }^{266}$ Disease thus represents a major ecological threat to the physical well-being of human beings and that threat is one that has been part of violent conquests of other peoples. The basic threat to ecological devastation as a part of warfare has an unfortunately deep history. ${ }^{267}$

Even in warfare, at least until World War II, and probably continuing in wars in emerging countries, more soldiers die as a result of disease than wounds. ${ }^{268}$ The reason for battlefield deaths through disease is that battlefields do not posses public health infrastructures. Battlefields are not designed for providing safe drinking water, shelter from the elements, and pristine latrines. What occurs on the battlefield can be a spillover effect from war itself insofar as public health infrastructures are destroyed as battles are fought or, in an age where the separation between civilian and military populations may not be valued, attacking the infrastructure may even be a tactical decision.

"War [is] not healthy for children and other living things." 269 The actual collision with weaponry can be fatal, but war also loosens diseases. Once disease outbreaks, as in the case of AIDS for instance, it is difficult to control it. Disease itself wreaks human ecological destruction in ways sometimes even more devastating than fighting battles.

\footnotetext{
${ }^{263} \mathrm{Id}$. at 195.

${ }^{264} I d$. at 195, 206-07. Diamond further argues that literacy also provided competitive advantages because literate societies were able to transmit knowledge that could make them more effective on any political endeavor that native peoples often could not duplicate through oral traditions. Thus, along with better weapons, nastier diseases, and central political organizations, literacy also contributed to military superiority. Diamond at 215-16.

${ }^{265}$ Caroline Baum, Global Economic Ties Solid, but Boycotts Still Worrisome, THE Los ANGELES BUSINESS JOURNAL, Apr. 7, 2003, at 12 (stating the globalization causes the free flow of labor and information to increase).

${ }^{266}$ Matt Wickenheiser, Idexx Begins Search for Mad-Cow Marker, PorTLAND PRESS-HERALD, June 15, 2003 (using mad-cow disease as an example of how a disease has jumped to humans from the consumption of animals, and the body does not recognize it as a disease and thus has no immunity to it).

267 See generally THE TRUE COST OF CONFLICT, supra note 5.

${ }^{268}$ Diamond, supra note 211, at 197.

${ }^{269}$ See, e.g. George Packer, The Way We live Now: Recapturing the Flag, N.Y. TIMES, Sept. 30, 2001, Section 6 (Magazine), at 15.
} 


\section{Conclusion}

In his interviews with leading CEOs, former Yale Business School Dean Jeffrey E. Garten concludes that CEOs should take "a broader agenda" that goes beyond philanthropy and beyond the typical commissions, trade, associations, and lobbying. ${ }^{270}$ That this has not been done is not a criticism of CEOs, he argues, but a missed opportunity. ${ }^{271}$ Similarly, it seems that not engaging business in a quest for sustainable peace is also a missed opportunity.

Businesses have power and influence. They are functioning, productive institutions. Corruption seems to be linked to violence. Gender equity seems to be correlated with less violence. Poverty resulting from lack of economic opportunity is linked to violence. Democratic kinds of participation and voice can be linked to peace. Corporations can help reduce corruption by being transparent. They can provide more equitable treatment of women. They can contribute to economic development and in ways that are widely distributed. They can be managed in a participatory way that embraces the voice of employees and other stakeholders and thus demonstrate democratic values.

Disease and war are linked. Diseases can be used as a weapon of war and can be a consequence as well. Disease has also served as a metaphor for war as well. Nobel Laureaute Albert Camus analogizes the isolating, suffocating and dehumanizing dimensions of the bubonic plague to the scourge of Naziism and war. ${ }^{272}$ Although many actors - governments, health authorities, and others - had primary responsibility for battling the plague, Camus's heroes were ordinary people who did their job the best they could each day and in doing so, made a continuous dent in the brutality of the disease. ${ }^{273}$ These bookkeepers, doctors, reporters, and others preserved a humanity threatened by disease.

Businesspeople too can make contributions daily to contribute to sustainable peace and reduce the potential of violence. Individually, no one person nor no one business is likely to prevent a war but businesspeople can make contributions that matter. Camus once wrote that "perhaps this world is one in which children suffer, but we can reduce the number of suffering children. And if you do not do this, then who will do this." 274 Today that can be paraphrased.

\footnotetext{
${ }^{270}$ JEFFrey C. GARTEN, THE Mind OF THE CEO 221 (2001).

${ }^{271} I d$. at 222.

${ }^{272}$ Albert Camus, The Plague (1947). See also Jean Kellogg, Dark Prophets of Hope 103-104, 117-18 (1975).

273 Timothy L. Fort, Who Will Clean Up the Mess? CHI. TriB., June 15, 1990, Section 1, p. 25.

${ }^{274}$ CAMUS, supra note 271.
} 
Perhaps this is a world in which there is warfare. But businesspeople can reduce the amount of violence in the world. And if they do not do this, then who will?

We propose sustainable peace as an aim to which businesses should orient their actions both for reasons of the good of avoiding the activities that contribute to the spilling of blood as well as for the promotion of sustainable economic enterprises, which are fostered by stable, peaceful relationships. Thus, business must do what it does best and address economic development, even in terms of the extraction of natural resources. But it must also be attentive to the rights of others, to the development of community and meaning, and to stop violence when it is likely. Given the dangers ecological stresses pose for the planet, it is hard to think of a more compelling reason to reorient business behavior. 


\section{DAVIDSON INSTITUTE WORKING PAPER SERIES - Most Recent Papers}

The entire Working Paper Series may be downloaded free of charge at: www.wdi.bus.umich.edu

CURRENT AS OF 5/17/04

\begin{tabular}{|c|c|c|}
\hline Publication & Authors & Date \\
\hline No. 698: Ecology and Violence: The Environmental Dimensions of War & $\begin{array}{l}\text { Timothy L. Fort and Cindy A. } \\
\text { Schipani }\end{array}$ & May 2004 \\
\hline $\begin{array}{l}\text { No. 697: Russian Cities in Transition: The Impact of Market Forces in } \\
\text { the 1990s }\end{array}$ & Ira N. Gang and Robert C. Stuart & May 2004 \\
\hline $\begin{array}{l}\text { No. 696: Firm Ownership and Internal Labor Practices in a Transition } \\
\text { Economy: An Exploration of Worker Skill Acquisition in Vietnam }\end{array}$ & Jed Friedman & May 2004 \\
\hline No. 695: The Unanticipated Effects of Insider Trading Regulation & $\begin{array}{l}\text { Art A. Durnev and Amrita S. } \\
\text { Nain }\end{array}$ & May 2004 \\
\hline $\begin{array}{l}\text { No. 694: Volatile Interest Rates, Volatile Crime Rates: A New } \\
\text { Argument for Interest Rate Smoothing }\end{array}$ & Garett Jones and Ali M. Kutan & May 2004 \\
\hline $\begin{array}{l}\text { No. } 693 \text { Money Market Liquidity under Currency Board - Empirical } \\
\text { Investigations for Bulgaria }\end{array}$ & $\begin{array}{l}\text { Petar Chobanov and Nikolay } \\
\text { Nenovsky }\end{array}$ & May 2004 \\
\hline $\begin{array}{l}\text { No. 692: Credibility and Adjustment: Gold Standards Versus Currency } \\
\text { Boards }\end{array}$ & $\begin{array}{l}\text { Jean Baptiste Desquilbet and } \\
\text { Nikolay Nenovsky }\end{array}$ & May 2004 \\
\hline $\begin{array}{l}\text { No. 691: Impact of Cross-listing on Local Stock Returns: Case of } \\
\text { Russian ADRs }\end{array}$ & Elena Smirnova & May 2004 \\
\hline $\begin{array}{l}\text { No. 690: Executive Compensation, Firm Performance, and State } \\
\text { Ownership in China:Evidence from New Panel Data }\end{array}$ & Takao Kato and Cheryl Long & May 2004 \\
\hline $\begin{array}{l}\text { No. 689: Diverging Paths: Transition in the Presence of the Informal } \\
\text { Sector }\end{array}$ & Maxim Bouev & May 2004 \\
\hline $\begin{array}{l}\text { No. 688: What Causes Bank Asset Substitution in Kazakhstan? } \\
\text { Explaining Currency Substitution in a Transition Economy }\end{array}$ & Sharon Eicher & May 2004 \\
\hline $\begin{array}{l}\text { No. 687: Financial Sector Returns and Creditor Moral Hazard: Evidence } \\
\text { from Indonesia, Korea and Thailand }\end{array}$ & $\begin{array}{l}\text { Ayse Y. Evrensel and Ali M. } \\
\text { Kutan }\end{array}$ & May 2004 \\
\hline $\begin{array}{l}\text { No. 686: Instability in Exchange Rates of the World Leading } \\
\text { Currencies: Implications of a Spatial Competition Model }\end{array}$ & $\begin{array}{l}\text { Dirk Engelmann, Jan Hanousek } \\
\text { and Evzen Kocenda }\end{array}$ & May 2004 \\
\hline $\begin{array}{l}\text { No. 685: Corporate Spinoffs, Privatization, and Performance in } \\
\text { Emerging Markets }\end{array}$ & $\begin{array}{l}\text { Jan Svejnar, Evzen Kocenda and } \\
\text { Jan Hanousekf }\end{array}$ & May 2004 \\
\hline $\begin{array}{l}\text { No. 684: CPI Bias and Real Living Standards in Russia During the } \\
\text { Transition }\end{array}$ & $\begin{array}{l}\text { John Gibson, Steven Stillman and } \\
\text { Trinh Le }\end{array}$ & May 2004 \\
\hline $\begin{array}{l}\text { No. 683: Mission Implausible III: Measuring the Informal Sector in a } \\
\text { Transition Economy using Macro Methods }\end{array}$ & Jan Hanousek and Filip Palda & May 2004 \\
\hline $\begin{array}{l}\text { No. 682: The Other Side of the Moon: The Data Problem in Analyzing } \\
\text { Growth Determinants }\end{array}$ & $\begin{array}{l}\text { Jan Hanousek, Dana Hajkova and } \\
\text { Randall K. Filer }\end{array}$ & May 2004 \\
\hline $\begin{array}{l}\text { No. 681: Consumers' Opinion of Inflation Bias Due to Quality } \\
\text { Improvements }\end{array}$ & $\begin{array}{l}\text { Jan Hanousek and Randall K. } \\
\text { Filer }\end{array}$ & May 2004 \\
\hline $\begin{array}{l}\text { No. 680: IMF-Related Announcements, Fundamentals, and Creditor } \\
\text { Moral Hazard: A Case Study of Indonesia }\end{array}$ & $\begin{array}{l}\text { Ayşe Y. Evrensel and Ali M. } \\
\text { Kutan }\end{array}$ & May 2004 \\
\hline No. 679: Privatization Matters: Bank Efficiency in Transition Countries & $\begin{array}{l}\text { John P. Bonin, Iftekhar Hasan and } \\
\text { Paul Wachtel }\end{array}$ & Apr. 2004 \\
\hline $\begin{array}{l}\text { No. 678: Does Market Liberalisation Reduce Gender Discrimination? } \\
\text { Econometric Evidence from Hungary, 1986-1998 }\end{array}$ & $\begin{array}{l}\text { Dean Jolliffe and Nauro F. } \\
\text { Campos }\end{array}$ & Apr. 2004 \\
\hline $\begin{array}{l}\text { No. 677: Governance and Performance of Microfinance Institutions in } \\
\text { Central And Eastern Europe and the Newly Independent States }\end{array}$ & Valentina Hartarska & Apr. 2004 \\
\hline $\begin{array}{l}\text { No. 676: Equilibrium Exchange Rates in the Transition: The Tradable } \\
\text { Price-Based Real Appreciation and Estimation Uncertainty }\end{array}$ & $\begin{array}{l}\text { Balázs Égert and Kirsten } \\
\text { Lommatzsch }\end{array}$ & Apr. 2004 \\
\hline $\begin{array}{l}\text { No. 675: Productivity growth and the real appreciation of the accession } \\
\text { countries' currencies }\end{array}$ & $\begin{array}{l}\text { Kirsten Lommatzsch and Silke } \\
\text { Tober }\end{array}$ & Apr. 2004 \\
\hline $\begin{array}{l}\text { No. 674: Exchange Rate Policy and Inflation in Acceding Countries: } \\
\text { The Role of Pass-through }\end{array}$ & $\begin{array}{l}\text { Fabrizio Coricelli, Boštjan Jazbec } \\
\text { and Igor Masten }\end{array}$ & Apr. 2004 \\
\hline No. 673: Is Kazakhstan a Market Economy Yet? Getting warmer.... & Sharon Eicher & Apr. 2004 \\
\hline
\end{tabular}

